\title{
PENGARUH AERASI PADA FERMENTASI PADAT TANDAN KOSONG KELAPA SAWIT OLEH ASPERGILLUS NIGER TERHADAP PRODUKSI GULA SEDERHANA
}

\author{
Himmatun Wisda, Wahyudi Budi Sediawan, Sarto \\ Magister Teknik Pengendalian Pencemaran Lingkungan, Departemen Teknik Kimia, Fakultas Teknik \\ Universitas Gadjah Mada, Jl. Grafika 2 Yogyakarta, Indonesia \\ Email: himmatun.wisda@mail.ugm.ac.id
}

\begin{abstract}
Abstrak
Telah dipelajari pengaruh aerasi pada produksi gula sederhana dari tandan kosong kelapa sawit (TKKS) dengan hidrolisis secara fermentasi padat menggunakan Aspergillus niger. Hasil gula sederhana diharapkan bisa difermentasi lanjut menjadi bioetanol. TKKS adalah biomasa lignoselulosa yang dapat diperbaharui dan sumbernya melimpah. Sebelum difermentasi, TKKS perlu diberi perlakuan awal (pretreatment) dengan larutan $\mathrm{NaOH} 1 \%$ pada suhu $150^{\circ} \mathrm{C}$ selama 2 jam. Produksi gula sederhana telah dianalisis menggunakan metode Dinitrosalicylic acid (DNS acid) dan diperoleh kadar tertinggi 9,102 g/L pada waktu inkubasi hari ke-3. Selain diproduksi, gula sederhana dikonsumsi pula oleh Aspergillus niger untuk pertumbuhan. Hal ini terlihat dari produk samping asam organik yang dihasilkan. Hasil percobaan menunjukan bahwa aerasi meningkatkan kadar gula sederhana. Untuk mempelajari lebih dalam proses ini, pemodelan kinetika reaksi diajukan dengan asumsi reaksi untuk proses hidrolisis maupun konsumsi gula. Pemodelan sederhana tersebut dapat mendeskripsikan secara kuantitatif proses fermentasi TKKS dengan cukup baik. Selain itu, diperoleh pula nilai parameter-parameter pada persamaan kinetika reaksinya.
\end{abstract}

Kata kunci: Aspergillus niger, TKKS, gula sederhana, fermentasi padat

\begin{abstract}
The effects of aeration on production of simple sugars by Aspergillus niger were investigated using oil palm empty fruit bunch (OPEFB) by solid state fermentation using Aspergillus niger. Simple sugars can further be fermented to produce bioethanol. OPEFB is renewable cellulosic biomass and largely available in Indonesia. Before being fermented, OPEFB needs to be pretreated. It was done by $\mathrm{NaOH} 1 \%$ solution at $150{ }^{\circ} \mathrm{C}$ for 2 hours. The concentrations simple sugars produced by hydrolysis were analyzed by Dinitrosalicylic acid (DNS). It turned out that the highest concentration of sugars was to be $9,102 \mathrm{~g} / \mathrm{L}$, and it was obtained on the $3^{\text {rd }}$ day of fermentation. Some parts of the sugars produced were consumed by Aspergillus niger itself for growth and maintenance. The experiment showed that aeration increased the simple sugars concentration. Modelling of reaction kinetic assumed to hydrolisis process and simple sugar consumed. Simply modelling can describe in quantitative fermentation of OPEFB. Moreover, get parameters value at equation of reaction kinetic.
\end{abstract}

Keywords: Aspergillus niger, OPEFB, simple sugar, solid state fermentation

\section{Pendahuluan}

Tandan kosong kelapa sawit merupakan salah satu limbah terbesar di Indonesia. Pertumbuhan luas area kelapa sawit selama 2004-2014 sebesar 7,67\%, sedangkan produksi kelapa sawit meningkat rata-rata $11,09 \%$ per tahun [3]. Dalam setiap pengolahan 1 ton TBS akan dihasilkan tandan kosong kelapa sawit sebanyak 22-23\% atau sebanyak 220-230 kg tandan kosong kelapa sawit [1]. Tandan kosong kelapa sawit tersebut hanya berakhir pada pengolahan limbah cair yang kemudian digunakan sebagai pupuk. Limbah tandan kosong kelapa sawit yang tidak tertangani akan menimbulkan pencemaran lingkungan dan menimbulkan berbagai penyakit. Limbah ini merupakan salah satu sumber energi yang cukup potensial dan pada umumnya merupakan bahan berselulosa yang dapat dikonversi menjadi bioetanol. Tandan kosong kelapa sawit mengandung $\quad 45,95 \%$ selulosa, $22,84 \%$ hemiselulosa, dan 16,9\% lignin [2].

Pemilihan tandan kosong kelapa sawit sebagai baku didasari oleh beberapa pertimbangan, antara lain: ketersediaan di Indonesia dan prospek kedepan dalam pengembangan bahan baku, kandungan dalam biomassa. Limbah tandan kosong kelapa sawit digunakan sebagai substrat dengan menggunakan mikroorganisme untuk penghasil enzim selulase. Aspergillus niger telah dikenal sebagai salah satu jenis mikroorganisme yang memiliki kemampuan yang tinggi untuk menghasilkan berbagai enzim yang penting penerapannya dalam industri. Aspergillus niger memiliki kelebihan dibandingkan jenis mikroorganisme lainnya yaitu mampu 
menghasilkan enzim selulase khususnya $\beta$ glukosidase dalam jumlah tinggi. Dalam metabolisme Aspergillus niger dapat menghasilkan asam organik lemah seperti asam sitrat, asam oksalat, dan asam glukonat [9]. Beberapa jenis enzim yang penting penerapannya dalam bidang industri yang dapat dihasilkan oleh Aspergillus niger adalah amilase, selulase dan amiloglukosidase [5].

Pretreatment merupakan suatu elemen penting dalam biokonversi substrat lignoselulosa. Adanya lignin dan hemiselulosa menyebabkan selulosa sulit untuk dihidrolisa. Pretreatment ini dilakukan dengan menggunakan $\mathrm{NaOH} 1 \%$ pada suhu $150{ }^{\circ} \mathrm{C}$ yang diautoklaf selama 2 jam. Adanya $\mathrm{NaOH}$ bertujuan untuk merusak struktur lignin sehingga memisahkan lignin dengan hemiselulosa [4].

Aspergillus niger bersifat aerobik. Oksigen merupakan salah satu faktor yang berpengaruh terhadap pertumbuhan mikroorganisme. Faktor yang mempengaruhi proses pertumbuhan jamur antara lain; konsentrasi substrat, sumber nitrogen, phospat, magnesium, aerasi, $\mathrm{pH}$, temperatur inkubasi, waktu fermentasi, dan moisture content [6]. Kecepatan aerasi merupakan faktor yang berperan dalam pemenuhan kebutuhan oksigen.

Tandan kelapa sawit mempunyai potensi besar sebagai substrat dalam produksi enzim selulase yang digunakan secara luas dalam industri sehingga penting untuk dilakukan. Penelitian ini dilakukan dengan menggunakan metode sistem fermentasi padat atau solid-state fermentation $(S S F)$. Sistem fermentasi padat umumnya diidentikkan dengan pertumbuhan mikroorganisme dalam partikel pada substrat. Beberapa keuntungan dari sistem fermentasi padat antara lain volume reaktor yang lebih kecil, kontaminasi bakteri lebih rendah, pemisahan produk lebih mudah, dan efisiensi energi. Proses fermentasi substrat padat menggunakan kadar kelembaban yang rendah. Kadar air pada SSF berkisar antara 40\% -80\%. [12]. Dalam penelitian ini, berfokus pada pengaruh aerasi terhadap biokonversi limbah TKKS menjadi gula sederhana. Selain itu, adanya usaha mendeskripsikan secara kuantitatif proses tersebut menjadi alasan keaslian penelitian.

\section{Teori}

Kinetika reaksi

Secara umum reaksi biokimia yang terjadi pada proses fermentasi pada substrat tandan kosong kelapa sawit dapat dituliskan sebagai berikut, [12]: substrat + sel $\rightarrow$ produk + sel baru Secara khusus dapat dituliskan,

$$
\begin{aligned}
& \mathrm{S}+\mathrm{X} \rightarrow \mathrm{P}+\mathrm{X} \text { baru } \\
& \mathrm{P}+\mathrm{X} \rightarrow \mathrm{M}+\mathrm{X} \text { baru }
\end{aligned}
$$

dengan $\mathrm{S}=$ selulosa,

$\mathrm{X}=$ Aspergillus niger

$\mathrm{P}=$ gula sederhana,

$\mathrm{M}=$ senyawa hasil metabolisme Aspergillus niger setelah mengkonsumsi gula sederhana.

\section{Mekanisme}

Aspergillus niger menghasilkan mengeluarkan enzim selulase untuk menghidrolisis selulosa pada TKKS. Selulosa selnjutnya terhidrolisis menjadi gula sederhana. Gula yang dihasilkan, dikonsumsi oleh Aspergillus niger untuk pertumbuhan dan maintenance. Sementara itu, laju konsumsi gula untuk maintenance setara dengan jumlah Aspergillus niger:

$$
r_{\text {main }}=\mu_{\text {main }} \cdot C_{X}
$$

Neraca massa selulosa dapat disusun sebagai berikut :

$\frac{d C_{S}}{d t}=-\mu_{h} \cdot C_{E}=-\mu_{h} \cdot \beta \cdot C_{X}=-\beta \cdot\left[\frac{\mu_{\operatorname{maxh}}}{K_{h}}\right] C_{s} \cdot C_{X}$

Pada kondisi ini $\mu_{\mathrm{h}}$ adalah jumlah enzim yang terdapat dalam sistem, dan diasumsikan berbanding lurus dengan jumlah jamur Aspergillus niger pada sistem.

Neraca massa gula mengikuti persamaan berikut ini :

$$
\begin{gathered}
\left(\begin{array}{c}
\text { Rate of } \\
\text { sugar } \\
\text { accumulation }
\end{array}\right)=\left(\begin{array}{c}
\text { Rate of } \\
\text { sugar } \\
\text { produced }
\end{array}\right)-\left(\begin{array}{c}
\text { Rate of } \\
\text { sugar } \\
\text { consumed for } \\
\text { growth }
\end{array}\right)-\left(\begin{array}{c}
\text { Rate of } \\
\text { sugar } \\
\text { consumed for } \\
\text { maintenance }
\end{array}\right) \\
\frac{d C_{P}}{d t}=\beta \cdot\left[\frac{\mu_{\operatorname{maxh}}}{K_{h}}\right] C_{S} \cdot C_{X} \cdot Y_{P / S}-\left[\frac{\mu_{\text {maxc }}}{K_{c}}\right] C_{p} \cdot C_{X}-\mu_{\text {main }} \cdot C_{X}
\end{gathered}
$$

Neraca massa jamur Aspergillus niger secara sederhana mengikuti model berikut ini :

$$
\frac{d C_{X}}{d t}=\mu_{c} \cdot C_{x} \cdot Y_{\frac{X}{P}}=\left[\frac{\mu_{\operatorname{maxc}}}{K_{c}}\right] C_{p} \cdot C_{X} \cdot Y_{X / P}-\alpha \cdot C_{X}
$$

Pembentukan asam organik oleh jamur Aspergillus niger dari mengkonsumsi gula 
$\frac{d C_{A}}{d t}=\mu_{c} \cdot C_{x} \cdot Y_{A / P}=\left[\frac{\mu_{\operatorname{maxc}}}{K_{C}}\right] C_{p} \cdot C_{X} \cdot Y_{A / P}$

Persamaan - persamaan tersebut dapat diselesaikan secara simultan dengan kondisi batas: $\mathrm{t}=0, \mathrm{C}_{\mathrm{S}}=\mathrm{C}_{\mathrm{S} 0}, \mathrm{C}_{\mathrm{P}}=0$, dan $\mathrm{C}_{\mathrm{x}}=\mathrm{C}_{\mathrm{x} 0}$.

\section{Metodologi Penelitian}

Bahan:

Bahan yang digunakan dalam penelitian ini antara lain; tandan kosong kelapa sawit (TKKS), Aspergillus niger, Potato dextrose agar (PDA), Aquadest, $\mathrm{NaOH}$ anhydrous, Tween 80, Garam Fisiologis $(\mathrm{NaCl}), \mathrm{KH}_{2} \mathrm{PO}_{4}$, yeast extract; $\quad \mathrm{CaCl}_{2}, \quad \mathrm{MgSO}_{4} 7 \mathrm{H}_{2} \mathrm{O}$, Dinitrosalycilid acid (DNS acid), Phenol, Natrium metabisulfit, Na-K-tartrat, $\mathrm{Na}_{2} \mathrm{CO}_{3}$, $\mathrm{CuSO}_{4} .5 \mathrm{H}_{2} \mathrm{O}$, Folin, dan Kertas saring.

Alat:

Alat yang digunakan dalam penelitian ini antara lain; Autoclave, gelas beaker, erlenmeyer, tabung reaksi, inkubator, pengaduk, pipet ukur, pipet tetes, labu takar, cawan petri, kawat ose, timbangan, api bunsen, screen/ayakan, kuvet, centrifuge, tabung centrifuge, kertas ph, Laminar Air Flow (LAF), kertas saring, oven, waterbath, vortex, kapas, aluminium foil, selang plastik, pompa akuarium mini, spektrofotometer, dan cuvet.

\section{Prosedur Penelitian:}

Pretreatment Substrat

TKKS dipotong dan dicacah hingga ukuran yang homogen. Ditimbang TKKS sebanyak 80 gram dan dimasukkan ke gelas beaker. Ditambahkan $\mathrm{NaOH} 1 \%$ ke dalam aquades 1200 $\mathrm{ml}$. Sampel TKKS diautoclave pada suhu 150 ${ }^{\circ} \mathrm{C}$ selama 2 jam. Air campuran dibuang dan TKKS dicuci berulang kali sampai $\mathrm{pH}$ netral. TKKS dipindahkan ke wadah dan dikeringkan dengan oven $60^{\circ} \mathrm{C}$ sampai berat stabil.

\section{Pembuatan Inokulum Aspergillus niger}

Sebanyak 39 gram potato dextrose agar (PDA) dilarutkan dalam $1000 \mathrm{ml}$ aquades. Larutan PDA disterilisasi dengan cara diautoclave pada suhu $121{ }^{\circ} \mathrm{C}$ selama 20 menit. Didiamkan dalam inkubator selama semalam dengan posisi miring agar didapatkan media agar miring (agar slane). Setelah PDA mengeras, digoreskan Aspergillus niger pada PDA untuk dikembangbiakkan.

Kultur Aspergillus niger

Jamur Aspergillus niger ditumbuhkan pada medium agar miring di dalam ruangan steril atau Laminar Air Flow (LAF). Kultur dilakukan dengan menggoreskan Aspergillus niger pada medium agar PDA. Aspergillus niger dapat digunakan setelah usia 7 hari.

\section{Fermentasi Substrat oleh Aspergillus niger} Jamur Aspergillus niger dipanen menggunakan vortex selama 10 menit dengan penambahan medium garam fisiologis $0,85 \%$. Sebanyak $4 \mathrm{ml}$ jamur Aspergillus niger dalam garam fisiologis ditambahkan ke 5 gram tandan kelapa sawit yang telah di-pretreatment, dan ditambahkan nutrien sebanyak $16 \mathrm{ml}$ ke dalam erlenmeyer. Fermentasi dimulai saat larutan nutrisi ditambahkan dengan kelembaban diatur pada $80 \%$. Untuk setiap $1 \mathrm{~L}$ medium basal (nutrien), terkandung $\mathrm{KH}_{2} \mathrm{PO}_{4} ; 20 \mathrm{~g}$, Yeast extract; $8 \mathrm{~g}$, $\mathrm{MgSO}_{4} 7 \mathrm{H}_{2} \mathrm{O} ; 5 \mathrm{~g}$, dan $\mathrm{CaCl}_{2} ; 5 \mathrm{~g}$ [10]. Sampel diambil pada hari ke-1, 2, 3, 4, 5, 6, 7, 8, 9, dan 10.

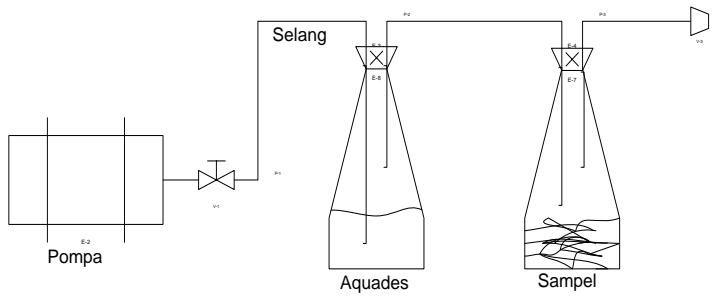

Gambar 1. Rangkaian Alat Proses Aerasi

\section{Pemurnian dan Pengambilan Sampel}

Sampel dipanen dengan sistem sentrifugasi menggunakan sentrifuge. Sampel di dalam erlenmeyer terlebih dahulu dicampur dengan 25 $\mathrm{mL}$ larutan $0,1 \%$ tween 80 . Sentrifugasi dilakukan selama 10 menit dengan kecepatan 6000 rpm. Cairan (supernatan) yang dihasilkan kemudian disaring dengan kertas saring agar terpisah dengan residu padatan.

\section{Analisis:}

Analisa gula pereduksi dengan menggunakan metode DNS. Analisa protein dengan menggunakan metode Lowry.

\section{Hasil}

Proses pretreatment menggunakan $\mathrm{NaOH}$ $1 \%$ pada suhu $150{ }^{\circ} \mathrm{C}$ selama 2 jam dilakukan dengan tujuan untuk mengurangi kadar lignin. Adanya lignin menyebabkan selulosa sulit untuk dihidrolisis. Hal ini dilakukan supaya lebih mudah untuk mengkonversi selulosa menjadi glukosa. Gula yang diperoleh tanpa pretreatment kurang dari 20\%, sedangkan dengan pretreatment dapat meningkat menjadi 90\% dari hasil teoritis [8]. Lignin yang terlarut 
dapat dilihat melalui filtrat hasil pretreatment yang berwarna hitam pekat. Komposisi lignoselulosa sebelum dan sesudah pretreatment dapat dilihat pada Tabel 1.

Tabel 1. Komposisi Lignoselulosa Hasil Pretreatment

\begin{tabular}{|l|c|c|}
\hline \multirow{2}{*}{ Komponen } & \multicolumn{2}{c|}{ Komposisi \% } \\
\cline { 2 - 3 } & Sebelum & Sesudah \\
\hline Selulosa & 41,06 & 50,8 \\
\hline Hemiselulosa & 9,39 & 3,3 \\
\hline Lignin & 24,7 & 19,9 \\
\hline
\end{tabular}

Terjadi penurunan konsentrasi hemiselulosa dari $9,39 \%$ menjadi $3,3 \%$ dan penurunan lignin dari 24,7\% menjadi $19,9 \%$. Hilangnya hemiselulosa dan lignin mengakibatkan persentase selulosa TKKS meningkat dari $41,06 \%$ menjadi $50,8 \%$. Larutan $\mathrm{NaOH}$ menyerang dan merusak struktur lignin pada bagian kristalin dan amorf serta memisahkan sebagian hemiselulosa [7].

Aspergillus niger merupakan jamur yang bersifat aerobik sehingga dalam pertumbuhannya membutuhkan oksigen. Aerasi ini berfungsi untuk mempertahankan kondisi aerobik untuk desorbsi $\mathrm{CO}_{2}$, mengatur temperatur substrat, dan mengatur kadar air [11]. Adanya sistem aerasi pada fermentasi TKKS oleh Aspergillus niger dapat meningkatkan produksi gula sederhana. Pengaruh adanya aerasi pada produksi gula sederhana dapat dilihat pada Gambar 1.

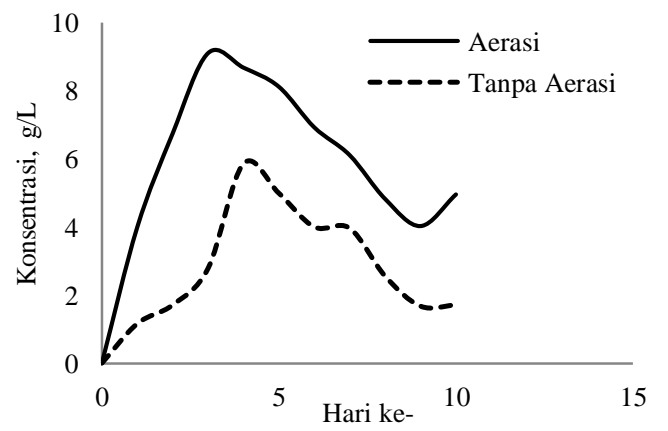

Gambar 2. Pengaruh Aerasi terhadap Produksi Gula Sederhana

Berdasarkan gambar tersebut, terlihat bahwa konsentrasi gula yang dihasilkan pada proses aerasi lebih tinggi dibandingkan dengan tanpa aerasi. Dengan adanya aerasi, konsentrasi tertinggi diperoleh sebesar 9,102 $\mathrm{g} / \mathrm{L}$ pada waktu inkubasi hari ke-3. Hal ini menunjukan bahwa adanya aerasi dapat meningkatkan kadar gula sederhana. Aspergillus niger mengalami pertumbuhan hingga mencapai puncaknya pada waktu tertentu dan akan mengalami penurunan. Selain diproduksi, gula sederhana dikonsumsi oleh Aspergillus niger untuk pertumbuhan.
Pertumbuhan jamur Aspergillus niger dilakukan dengan mengukur kadar protein yang dihasilkan. Kadar protein tersebut merupakan indikator jumlah mikroba yang terkandung di dalam enzim yang dikeluarkan oleh Aspergillus niger. Pengaruh oksigen terhadap pertumbuhan jamur yang terbentuk ditunjukkan oleh peningkatan konsentrasi protein. Konsentrasi protein sepanjang waktu fermentasi tersaji pada Gambar 3.

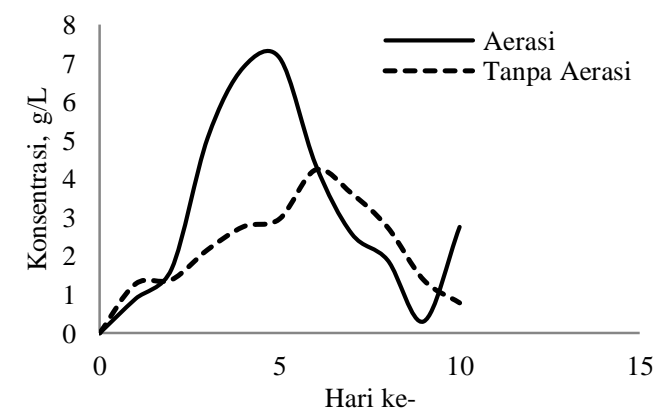

Gambar 3. Pengaruh Aerasi terhadap Pertumbuhan Aspergillus niger

Konsentrasi protein yang dihasilkan dengan adanya aerasi lebih tinggi dibandingkan dengan tanpa aerasi. Kadar protein tertinggi dihasilkan pada hari ke yaitu ke-5 sebesar 7,130 g/L. Hal ini menunjukan bahwa adanya korelasi antara pertumbuhan jamur dengan kadar protein yang dihasilkan.

Aspergillus niger menghidrolisis selulosa untuk mendapatkan glukosa. Selama proses hidrolisis, Aspergillus niger mengkonsumsi glukosa untuk pembentukan massa sel dan produk metabolit dan juga pemeliharaan sel [14]. Pada penelitian ini terjadi penurunan $\mathrm{pH}$ sebagai indikasi metabolit hasil metabolisme Aspergillus niger. Besarnya laju konsumsi glukosa dipengaruhi oleh laju pertumbuhan Aspergillus niger [13].

Pemodelan kinetika yang disusun dilakukan untuk mengetahui konstantakonstanta reaksi. Penyelesaian untuk model tersebut juga dibantu dengan Matlab 2013a dan Microsoft Excel 2010. Hasil simulasi dari perbandingan antara grafik perubahan konsentrasi gula sederhana sepanjang waktu fermentasi dengan hasil pemodelan dapat dilihat pada Gambar 4. 


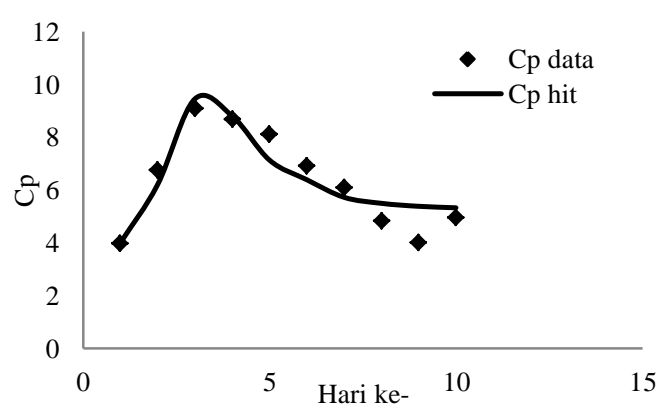

Gambar 4. Perbandingan Produksi Gula Sederhana Hasil Penelitian dan Gula Sederhana Hasil Perhitungan Model Kinetika

Model kinetika yang diajukan mendekati hasil pengukuran pada penelitian ini. Kesesuaian model kinetika dengan hasil pengujian produksi gula sederhana ditunjukkan oleh nilai Sum Square Error (SSE) yang kecil. Pemodelan sederhana tersebut dapat mendeskripsikan secara kuantitatif proses fermentasi TKKS dengan cukup baik. Selain itu, diperoleh pula nilai parameter pada persamaan kinetika reaksinya.

\section{Kesimpulan}

1. Pretreatment dengan $\mathrm{NaOH} 1 \%$ pada suhu $150^{\circ} \mathrm{C}$ akan meningkatkan produksi gula sederhana pada hidrolisa TKKS oleh jamur Aspergillus niger.

2. Adanya sistem aerasi pada fermentasi TKKS oleh Aspergillus niger dapat meningkatkan produksi gula sederhana.

3. Pemodelan sederhana yang diajukan mendeskripsikan secara kuantitatif proses fermentasi TKKS dengan cukup baik. Selain itu, diperoleh pula nilai parameter-parameter pada persamaan kinetika reaksinya.

\section{Daftar Pustaka}

[1] Alhidayatullah, Sudirman LI, Dharmaputra OS, Kemampuan jamur pelapuk kayu isolat JPA dan Trichoderma Sp. S2-2 dalam mendegradasi tandan kosong kelapa sawit untuk menghasilkan selulosa, Menara Perkebunan, (2014) 82(2): 51-56.

[2] Darnoko, Z. Poeloengan dan I. Anas, Pembuatan Pupuk Organik Dari Tandan Kosong Kelapa Sawit, Buletin Penelitian Kelapa Sawit, 1992, 2: 89-99.

[3] Direktorat Jenderal Perkebunan, Pertumbuhan Areal Kelapa Sawit Meningkat, http://ditjenbun.pertanian. go.id/berita-362-pertumbuhan-areal-

kelapa-sawit-meningkat. html, 2014, diakses pada 22 Desember 2015.
[4] Enari, Cellobiohydrolase from Trichoderma reesei, Biochem J, (1983) 215(3): 677-683.

[5] Frazier and Westhoff, Food Microbiology, Tata Mc Graw Hill Publ. Co.Ltd, New York, 1981, p. 275-282.

[6] Gandjar, Indrawati dan Wellyzar Sjamsuridzal, Mikologi Dasar dan Terapan, Yayasan Obor Indonesia, Jakarta, 2006, p.126.

[7] Gunam, I.B.W., \& Antara, N.S., Study on sodium hydroxide treatment of corn stalk to increase its cellulose saccharification enzymatically by using culture filtrate of Trichoderma reesei, Gitayana, Agric. Technol. J, (1999) 5(1): 34-38.

[8] Hamelinck, C.N., G. van Hooijdonk, and A.P.C. Faaij, Ethanol from lignocellulosic biomass: Techno-economic performance in short-, midle- and long-term, Biomass and Bioenergy, (2005) 28: 384-410.

[9] Inggrid, M. dan Suharto, I.. Fermentasi Glukosa oleh Aspergillus niger Menjadi Asam Glukonat, Lembaga Penelitian dan Pengabdian Masyarakat, Universitas Katolik Parahayangan, Bandung, 2012.

[10] Kang, S.W., Park, Y.S., Lee J.S., Hong S.I., Kim S.W.,. Production of cellulases and hemicellulases by Aspergillus niger KK2 from lignocellulosic biomass, Bioresource Technology, (2004) 91: 153156.

[11] Prior B. A., Du Preez, J. C., and Rein, P. W. Environmental Parameters in Doelle, H. W Mitchell and Rolz, C (eds) Solid State Cultivation. London, Elsevier, 1992, p.65-85.

[12] Shuler, M. L. and Kargi, F., Bioprocess Engineering: Basic Concepts, ed 2nd, , Prentice Hall P T R, Englewood Cliffs, New Jersey, 2002, p. 61-63.

[13] Widiyanti, S. E., Tesis, Kinetika Konsumsi Glukosa oleh Aspergillus niger dalam Produksi Bioethanol dari Lignoselulosa, Departemen Teknik Kimia Fakultas Teknik Universitas Gadjah Mada Yogyakarta, 2014.

[14] Znad, A., Blazej, M., Bales, V., and Markos, J., A kinetic model for gluconic acid production by Aspergillus niger, Chem. Pap., 2003,58(1): 23-28. 